\title{
O REI NAS MINAS: A CONSTRUÇ̃̃o SIMBÓLICA do IMPÉRIO PORTUGUÊS NA CAPITANIA dE MINAS GERAIS
}

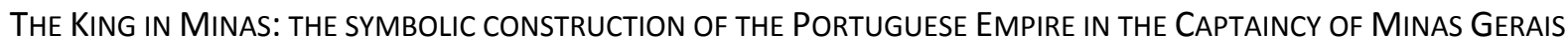

Pablo Menezes e Oliveira* pablo.menezes@oi.com.br

RESUMO: No final do século XVII a Coroa portuguesa foi informada da existência de ouro em seus domínios americanos, inaugurando sua "idade do ouro". A descoberta gerou um processo de colonização que movimentou grande número de pessoas para a região depois denominada Minas Gerais, demandando a instalação de um grande aparato burocrático, que permitisse normatizar as gentes e as atividades econômicas que ali tiveram lugar. Além de uma estrutura normativa e fiscalista também foram instalados aparatos simbólicos para consolidar a imagem do rei na região. Foram promovidas festividades na Capitania, bem como circularam imagens e símbolos que evocavam o poder régio, quando o rei e a monarquia eram celebrados, importante estratégia para conferir um esteio comum aos povos que compunham o Império. Aqui pretendemos mostrar como as casas de câmara participaram deste processo, por meio das ações que promoveram em Minas Gerais no século XVIII.

PALAVRAS-CHAVE: Festas, câmaras, Império.

ABSTRACT: At the end of the $17^{\text {th }}$ century, the Portuguese Crown was informed of gold existence inside its American domains, inaugurating its "golden age". The discovery led to a process of colonization that moved a large number of people to the region later called Minas Gerais, requiring the formation of a large bureaucratic state in the region that would allow normalizing the people and the economic activities that took place there. Besides creating a regulatory and taxing structure, the Crown provided the region with a symbolic apparatus to consolidate the king's presence in the region. Various festivities were held in the various stops of the Captaincy, and monarchical images were circulated to give a common support to the people who were part of the Empire. Here we intend to show how the Councils participated in this process through the actions promoted in Minas Gerais in the $18^{\text {th }}$ century.

KEYWORDS: celebration, council, Empire.

No final do século XVII, a Coroa portuguesa recebeu informações de que havia sido encontrado ouro no "sertão" da América portuguesa, em área até então pouco conhecida, denominada Sertão dos Cataguases. ${ }^{1}$ Este feito derivou do desbravamento da região a partir das expedições promovidas pelos paulistas - denominadas bandeiras - que teriam ocorrido desde meados do século XVI. No século XVII, Portugal, passando por uma crise econômica, incentivou o desbravamento do interior da América, procurando novas formas de complementar sua economia. A descoberta realizada pelos paulistas trazia consigo a

\footnotetext{
* Doutor em História pela Universidade Federal de Minas Gerais (2013). Professor do Instituto Federal de Minas Gerais - Campus Congonhas.

${ }^{1} \mathrm{O}$ topônimo "Minas Gerais" teria aparecido logo em princípios do século XVIII. Segundo consta em um relato setecentista, o termo nasceu do grande número de minas descobertas, que foram denominadas Minas Gerais. Além do referido termo, foram utilizados os termos "Sertão dos Cataguases", "Campos Gerais dos Cataguases", "minas gerais dos Cataguás", "minas gerais do ouro", "distrito das minas gerais", escrito em minúsculo até 1706, quando passa a ser grafado “Minas" ou “Minas Gerais" (FONSECA, 2005, p. 67).
}

Hist. R., Goiânia, v. 21, n. 1, p. 114-130, jan./abr. 2016

Recebido em 31 de setembro de 2015 Aprovado em 29 de novembro de 2015 
expectativa de ampliar as combalidas receitas régias, mas faria com que fosse necessária uma grande reestruturação da estrutura administrativa e militar em solo americano, movimentando grande número de burocratas para dar ordem às atividades econômicas ligadas à exploração aurífera, bem como à vida dos povos que a estas se ligavam direta e indiretamente. Isso porque a atividade mineral fez com que grande número de pessoas, oriundas de várias partes dos domínios lusitanos, e mesmo de Portugal, migraram para Minas Gerais, ficando as áreas recém-descobertas inundadas de acampamentos de mineiros, que realizavam as artes de minerar nos leitos e morros. $\mathrm{O}$ estabelecimento de povoados nas regiões mineradoras teve como consequência um convívio muito grande entre os povos, sendo muito pequeno o número de burocratas e militares ali existentes nos primeiros anos. Disso resultou uma série de conflitos, que fez com que fosse necessária a normatização da população. Além disso, havia a necessidade de tributar, que demandava uma estrutura bastante engenhosa. Isso porque o ouro era equivalente universal, o que fazia seu potencial de circulação ser muito grande, pois não precisava ser vendido para dar ao minerador recursos para ter acesso a bens materiais. Por tal motivo as autoridades portuguesas tiveram que viver às voltas com a melhor forma de tributar as atividades minerais de modo que a parte que cabia à Coroa estivesse assegurada. Era uma situação de certa forma nova, considerando a experiência com a prática de tributar as atividades agroexportadoras até então experimentadas por Portugal, caso da produção do açúcar. Este gênero só gerava recursos financeiros para o agricultor com sua comercialização, em parte feita na Europa. Assim, a separação oceânica entre a produção e venda fazia com que a coroa tivesse bastante êxito na tarefa de tributação (ANASTASIA, 1998, p. 16). Assim, as atividades econômicas e o fluxo populacional explicam a grande movimentação burocrática experimentada pelos distritos minerais.

Sabe-se que tal movimento não fora imediato, e a estrutura administrativa de Minas Gerais foi arquitetada gradativamente, conforme as expectativas econômicas e o fluxo populacional foram aumentando. Assim, de posse da informação de existência de ouro nas Minas, mas sem saber o futuro que reservava a empreitada mineral, o Rei entregou a administração dos distritos minerais às pessoas que haviam se envolvido no processo de descobrimento do ouro. Mas é preciso registrar que a outorga de cargos na administração régia não era apenas por temeridades em torno das atividades minerais: era também o 
cumprimento daquilo que havia sido prometido aos descobridores das minas, qual seja, a concessão de cargos na administração dos distritos mineradores (CAMPOS, 2002, p. 45-46).

Com o decurso dos anos, o desbravamento do território fez aumentar o número de minas auríferas, especialmente as minas de beta - consideradas mais "duráveis". Na esteira deste processo, pessoas oriundas de várias partes dos domínios de Portugal, e, do reino, começaram a se instalar em Minas. Em alguns casos este processo migratório resultou na disputa por zonas de poder, que se intensificaram considerando a rala estrutura administrativa instalada na região. Um episódio mais emblemático deste período ocorreu por volta de 1707, quando paulistas - naquele momento inseridos na estrutura administrativa na condição de descobridores das minas - conflitaram com povos oriundos de outras partes da América e do reino, em conflito que seria mais tarde denominado "Guerra dos Emboabas" (ROMEIRO, 2008).

O embate marcou significativamente a história da ocupação de Minas Gerais. O conflito de interesses entre os paulistas e aqueles que vinham migrando para os distritos minerais resultou em uma tensão que tinha como objetivo ter papel de destaque na estrutura de poder que começava a se desenhar para a região. Isso porque muitos "emboabas" começavam a se destacar em suas atividades econômicas, como a mineração e o comércio, e, gradativamente, começavam a reivindicar cargos na administração dos distritos minerais. ${ }^{2}$ É preciso registrar que Minas, em seus primeiros tempos, tinha um quadro sociopolítico marcado por potentados, disputas por lavras, em meio a uma discreta presença do Estado. Era assim um espaço marcado pela violência interpessoal. A Guerra dos Emboabas teria sido deflagrada tendo esse pano de fundo. Segundo Adriana Romeiro, "a deflagração do conflito armado resultou no atrito entre dois territórios de mando, liderados por um paulista e um forasteiro, este último suficientemente fortalecido para confrontar a autoridade do grupo então dominante" (ROMEIRO, 2008, p.93).

Diante dos conflitos cada vez mais graves, a Coroa portuguesa se viu na necessidade de arquitetar um meio através do qual o território fosse mais bem administrado, colocando os povos debaixo das leis e ordem régia. Um dos capítulos mais importantes deste esforço se

\footnotetext{
2 Exemplos deste processo, dois "forasteiros" receberam cargos na administração de Minas Gerais: Em 1706 Francisco do Amaral Gurgel recebeu a patente de capitão-mor de Ouro Preto, e no ano seguinte Pascoal da Silva Guimarães recebeu patente de sargento-mor das minas de Ouro Preto. Sobre o tema: Romeiro, 2008, p. 125.
} 
deu em 17 de julho do ano de 1709, ocasião em que o Conselho Ultramarino se reuniu para discutir sobre qual seria o melhor meio para administrar as Minas, com o objetivo de discutir sobre ações que deveriam ser adotadas para administrar a região de maneira eficiente, para "pôr em melhor forma o governo daquelas terras" (CONSULTAS DO CONSELHO ULTRAMARINO, 1951, p. 219-242). No extenso documento, consta que o êxito na tarefa de administrar os distritos minerais dependia de alguns fatos: a defesa da costa do Rio de Janeiro, afinal, é preciso considerar o temor quanto aos inimigos externos, que poderiam tomar os distritos minerais, sendo o Rio de Janeiro uma porta de entrada; a administração da justiça, um dos atributos centrais do rei; o governo político das Minas, pois era necessário que os habitantes vivessem regulados pelas leis; a arrecadação dos quintos, que como veremos será matéria constante na administração de Minas Gerais ao longo do século XVIII.

No que diz respeito à administração de Minas, os conselheiros entendiam que deveriam ser remetidos a Minas não apenas uma só pessoa, mas umas tantas que pudessem constituir na região um governo "cristão e político", que ficariam encarregadas de fundar igrejas, constituir párocos, fundar vilas e povoações, ${ }^{3}$ ordenar milícias, estabelecer a arrecadação dos quintos e dos dízimos. Entre estes pontos, nos interessa observar a fundação de vilas e povoações, discutida pelo Conselho. Ao lançar luz sobre o significado destes termos no universo setecentista, pode-se constatar que eram instituições imediatamente ligadas à administração, considerando que nestas havia uma casa de câmara, instituição sobre a qual nos estenderemos mais à frente. Grande parte das medidas sugeridas pelo Conselho Ultramarino seria aplicada a Minas Gerais dois anos após a referida reunião pela autoridade que deveria assumir a administração dos distritos mineradores e São Paulo, na função de governador recém criada Capitania de São Paulo e Minas de Ouro. Em novembro de 1709, o experiente Antônio de Albuquerque Coelho recebeu instruções para o governo da nova capitania, por meio de documento produzido à luz dos temas e

\footnotetext{
${ }^{3}$ O termo vila significava, segundo Vocabulario Portuguez \& Latino, de Raphael Bluteau, publicado em 1728, "Povoação aberta, ou cercada, que nem chega a cidade, nem é tão pequena, como aldeia. Tem juiz, e senado de câmara, e seu pelourinho". BLUTEAU, 1728, p. 489. Já o Diccionario da língua portuguesa, de Antônio de Moraes Silva, publicado em 1789, informava que Vila era "povoado de menor graduação que a cidade, e superior a aldeia, tem juiz, câmara e pelourinho". SILVA, 1789, p. 481. Para o termo povoação, segundo Raphael Bluteau, eram "os moradores de um lugar, vila ou cidade, ou o mesmo lugar, vila ou cidade, como quando se diz, grande ou pequena povoação". BLUTEAU, 1728, p. 662. Para Antônio de Moraes Silva, publicado em 1789, informava que povoação seria "a gente, que habita em algum lugar, vila, ou cidade. O lugar povoado". SILVA, 1789, p. 481
} 
questões levantadas na reunião do Conselho de julho do mesmo ano (Nomeação de Antônio de Albuquerque, 1906, p. 685-686). ${ }^{4}$

Assim que chegou a Minas, teve a tarefa de colocar em sossego os povos então levantados com a guerra dos emboabas. Com o objetivo de pôr um fim à situação em que Minas se encontrava, entrou sem grandes cerimônias em Minas, tendo em sua companhia apenas uma pequena escolta, e rapidamente dirigiu-se para Caeté, local onde se encontrava os líderes dos Emboabas, e negociou o fim dos conflitos, concedendo perdão geral aos revoltosos. Com isto, conseguiu apaziguar as tensões, e pôde colocar em curso o projeto de iniciar uma nova etapa na administração da região, em conformidade com aquilo que havia sido estabelecido pelo Conselho Ultramarino (CAMPOS, 2002, p. 95). Entre estas, Albuquerque entendeu que deveria fundar municipalidades na região, instalando no coração da América portuguesa casas de câmara, instituição já notoriamente conhecida pela Coroa na condução da administração de Portugal e seus domínios.

As municipalidades faziam parte da estrutura administrativa do Império português, sendo consideradas um de seus pilares, expressão imortalizada por Charles Boxer (2001). Concordes com a afirmação do autor, observamos que os oficiais das câmaras tinham obrigações relacionadas à administração, fisco, justiça e defesa, que se ampliavam em atribuições diversas. De acordo com a legislação pertinente às atribuições camarárias, que se encontram transcritas nas Ordenações Filipinas, os oficiais das câmaras, como eram conhecidos, deveriam supervisionar a distribuição e arrendamento das terras municipais e comunais, lançar e cobrar taxas municipais, e em alguns casos tributos régios, fixar preços de produtos e provisões e passar licença aos vendedores ambulantes. ${ }^{5}$ Também deveriam zelar pela qualidade dos gêneros postos à venda, cuidar da regularidade do abastecimento e supervisionar os abatedouros públicos. Este ponto era essencial, pois a falta de gêneros, ou a má qualidade destes podiam gerar graves distúrbios à ordem pública. Ordenavam a estrutura urbana da vila, pela concessão de licenças para a construção de edifícios

\footnotetext{
${ }^{4}$ Antônio de Albuquerque Coelho e Carvalho (1655-1725) contava com cinquenta e três anos na época da posse. Era um dos homens mais experientes e importantes dos quadros régios, com larga experiência administrativa e militar. Havia servido no Maranhão por duas vezes, em 1667-1671 e entre 1678-1701, quando foi responsável pela expulsão dos franceses das Guianas. Sua experiência bélica teria servido para gerenciar as tensões da recém-criada Capitania de São Paulo e Minas de Ouro em 1709. O mesmo conhecimento militar foi útil dois anos mais tarde, quando seguiu para o Rio de Janeiro para lutar pela expulsão dos franceses da região (ROMEIRO, 2002, p. 288).

${ }^{5}$ Grande parte das atribuições dos chamados oficiais das câmaras pode ser encontrada nas Ordenações Filipinas, Livro I, Título 66.
} 
particulares, e da construção e manutenção de estradas, pontes, fontes, cadeias e demais bens públicos. Deveriam regular os feriados e organizar procissões e festividades cívicas e religiosas, policiar as localidades sob sua jurisdição, fazer serem cumpridos os códigos de posturas, e publicar os editais régios. Na área judiciária, atuavam como uma espécie de tribunal de primeira instância, subjugados ao ouvidor mais próximo ou mesmo ao Tribunal da Relação. Em certos casos, as câmaras exerceram também a função de prestar "serviços sociais". Cuidaram dos enjeitados e órfãos, por meio da atuação dos juízes de órfãos, e da contratação de criadeira de expostos. Também foram responsáveis pela instrução pública, por meio da contratação de professores para lecionar as primeiras letras. Esse grande número de atribuições, dentro de um império exíguo em oficiais, fez com que muitas câmaras nas variadas partes dos domínios portugueses, assumissem um lugar de destaque na administração do Império (BICALHO, 2001, p. 193; RUSSEL-WOOD, 1977, p. 27). Por tudo o que representavam as municipalidades, a sugestão de que fossem instaladas na região em Minas Gerais, proposta no Conselho Ultramarino no ano de 1709 , depois reforçadas nas instruções recebidas por Antônio de Albuquerque no mesmo ano, representava uma tentativa de instalar ali o poder e ordem régia.

A Capitania de Minas Gerais, ao longo do século XVIII, assistiu à fundação de 14 vilas e uma cidade. As fundações aconteceram de forma descontinuada, reverberando interesses múltiplos das autoridades portuguesas na tentativa de normatizar as atividades econômicas e a população. O primeiro momento de constituição das municipalidades ocorreu entre os anos de 1711 e 1718, quando vilas foram fundadas em Minas como reposta à migração em massa que os descobertos auríferos provocaram para a região das Minas, que, em muitos casos, resultaram em distúrbios e disputas por lavras. As vilas criadas neste período foram: Vila de Nossa Senhora do Carmo, Vila Rica e Vila Real de Sabará, todas em 1711; Vila de São João d'el Rey, em 1712; Vila do Príncipe e Vila Nova da Rainha, em 1714; Vila Nova do Infante, em 1715 e; Vila de São José d'el Rey, em 1718. No ano de 1730 foi instituída a Vila de Bom Sucesso na região mais ao norte da Capitania. A coroa passaria longos anos sem fundar novas municipalidades, até que entre os anos de 1789 e 1798 resolveu instalar cinco novas vilas em Minas. Neste período foram fundadas as Vilas de São Bento do Tamanduá, em 1789; a Vila de Queluz, em 1790; a Vila de Barbacena, em 1791 e; as Vilas de Campanha da Princesa e de Paracatu do Príncipe, no ano de 1798. A única cidade de Minas Gerais 
fundada no século XVIII foi a Cidade de Mariana, processo derivado da elevação da Vila de Nossa Senhora do Carmo à Cidade, em 1745, ocasião em que se tornou sede do bispado instalado na Capitania de Minas Gerais no mesmo ano (OLIVEIRA, 2005).

Instaladas em Minas Gerais, as Câmaras procuraram atender as comunidades a que se relacionavam nas várias matérias que eram de sua responsabilidade. Construíram fontes, chafarizes, edifícios públicos e procuraram regular o abastecimento dos povos. Atuaram também contra aqueles que causavam prejuízos aos locais com suas atitudes, como mineradores, clérigos e autoridades despóticas. Mas também foram de fundamental importância para sedimentar a cultura partilhada pela monarquia portuguesa pelos habitantes de seu vasto império, espalhando na Capitania de Minas Gerais a cultura lusitana entre os povos, através da produção de símbolos que estavam ligadas a monarquia.

Além de dotar o espaço urbano de equipamentos vários, as Câmaras foram responsáveis pela promoção de festividades e representações pictóricas ligadas à família real. Estes eventos foram muito importantes na consolidação do poder régio entre os povos. Segundo as Ordenações Filipinas, as câmaras deveriam realizar, anualmente, algumas celebrações que faziam parte do calendário religioso como o Corpus Christi, a Visitação de Nossa Senhora Aparecida e o Anjo Custódio do Reino para além dos nascimentos, casamentos e exéquias de membros da Família Real. Para realizarem essas celebrações, as Câmaras se encarregavam de contratar músicos para tocar nos cortejos, sacerdotes para fazer o sermão, comprar a cera e o incenso, organizar as touradas e cavalhadas, consertar as imagens confessionais e convidar as autoridades régias que deveriam tomar parte no evento (SANTIAGO, 2003, p. 13).

A relação entre monarcas portugueses e as celebrações existiam desde tempos remotos, e seguiam a intenção de celebrar a Coroa portuguesa e a Igreja. Até o reinado de D. João II (1481-1495), o rei não se distanciava dos súditos nos festejos. A partir dessa época, com a crescente centralização política, as festas passaram a compor um "leque interpretativo" do rei e seu poder, separando o rei dos súditos, colocando-o em local distinto. A partir do reinado de D. Manuel (1495-1521), as festas foram inseridas na legislação do Estado, tornando-se obrigatória a alguns segmentos da administração. O Rei D. João V (1707-1750) explorou com grande propriedade as festas como meio de representar seu poder. Durante seu reinado, destacam-se os festejos por ocasião de seu casamento, em 
1708; o início da construção do convento de Mafra, em 1717; e o casamento de seus filhos, no ano de 1729. No programa festivo, estavam incluídos iluminação, fogos de artifício, arquitetura efêmera, música, decoração das ruas, sermões e procissões. Estas festividades acentuavam símbolos, alegorias, imagens referentes ao soberano, tornando-o parte ativa e presente no seio da cerimônia. Os festejos relativos à família real construíam, por meio de um "regozijo comum", uma identidade entre a Coroa e os súditos das mais diversas paragens do império, consolidando sua imagem entre seus vassalos (SANTIAGO, 2003, p. 4041).

Todas as mobilizações festivas acima aludidas aconteciam com bastante frequência em Minas Gerais ao longo do século XVIII. Em Vila Rica, os acórdãos da câmara registram com frequência a mobilização da câmara em torno de festividades. Uma correspondência do ouvidor da comarca de Vila Rica confirmava sua presença na festa de Corpus Christi que aconteceu no ano de 1717, portanto, seis anos após a instalação da municipalidade (SANTIAGO, 2003, p. 86). No ano de 1726, os camaristas de Vila Rica informaram ao rei a ocorrência de celebrações em comemoração ao nascimento do infante D. Alexandre. A celebração procurou cumprir a maior pompa possível, cuidando para que a celebração fosse grandiosa, tanto nos ritos, como nas vestimentas daqueles que deveriam fazer parte dela. Segundo os camaristas, as festividades ocorreram da seguinte forma:

huma festa solene de igreja com porcição p. $^{\text {a } ~ o ~ q u e ~ s e ~ d e r a ̃ o ~ d e ~ p r o p i n a s ~}$ aos off. ${ }^{\text {aes }}$ da cam. ${ }^{\text {ra }}$ gastos de sera nas luminarias de tres dias, e gallas tanto a cortezan de capas abandadas como vestidos em corpo, p. $^{\text {a com esta }}$ deferença completar os nossos dezejos o alto de sua liberdade durando tres dias este obzequio [...] (Arquivo Histórico Ultramarino - AHU. Caixa 5, Documento 70$)^{6}$

Passados alguns anos da instalação de municipalidades nos distritos minerais, as celebrações começaram a participar dos calendários festivos. Muitas delas com grande pompa e uso de grandes somas de recursos. Isso, eventualmente, foi motivo de desentendimentos entre os camaristas, que em geral organizavam estas celebrações, e as autoridades, que deveriam supervisionar os gastos destas ocasiões, como os ouvidores. Algumas destas questões foram inclusive objeto de atenção do Conselho Ultramarino, segundo documentação remetida a este Conselho pela Câmara de Vila Rica em 1724:

\footnotetext{
${ }^{6}$ Toda a documentação a que nos referimos neste artigo com a denominação "Arquivo Histórico Ultramarino" que apresentamos com a abreviação "AHU", trata-se dos documentos referentes a Minas Gerais compiladas pelo Projeto Resgate, e disponibilizada em CD-ROM.
} 
atendendo a estas circunstâncias e ao discomodo, perjuizo, e despezas com q os juízes e vereadores vem asistir a sua obrigação, foi percizo darçe de ajuda de custo a cada hum dos dittos off. ${ }^{\text {es }}$ cento e cincoenta outavas de ouro por entendermos era inda limitada esta consignação $p .^{a}$ os gastos com q era forcozo asistir. E como he uso darçe ao corregedor da comarca o dobro de quaesquer porpinas q se offerecem dando nôs ao Doutor Antônio Berquo Del Ryo por exerçer o d. ${ }^{\circ}$ lugar trez. ${ }^{\text {as }}$ outavas de ouro elle o impunou e som. ${ }^{\text {e }}$ fes aseitação de duz..$^{\text {os }}$, mostrando nisto o dezejo que tinha de obsequiar este acto com menos despeza, de que damos a $\mathrm{V}$. Mag. ${ }^{\text {de }}$ parte $p^{\text {a }}$ que sua real grandeza haja por bem feito o que nesta matéria detriminamos (AHU. Caixa 5, Documento 70).

Segundo os camaristas, para participar das festividades solenes as autoridades da Capitania recebiam propinas, que deveriam auxiliar nos custos para a participação no evento. Aparentemente, por terem sido generosos com suas próprias propinas, os vereadores acabaram por ter que aumentar os valores repassados ao ouvidor da Comarca, e, no final, as propinas alcançaram grandes somas. Os membros do Conselho Ultramarino postaram-se contrariamente a essa prática. Segundo o parecer que omitiram sobre o tema:

esta despesa parece excessiva, e como não havia ordem nem provizão alguma . $^{\text {a }}$ se fazer, justo hera se mandasse rifar porem como se assim possa rezultar algum escandalo, principal. ${ }^{\text {te }}$ sendo nos soberano o motivo $q$ os escuza, me parecia q com attenção a ella, se lhe devia aprovar a despeza de q se dá comta e p. $^{\text {a }}$ o futuro regularen se as propinas $q$ haver $q .^{\text {to }}$ esta importante (AHU. Caixa 5, Documento 70).

Mesmo deferindo os gastos com as festividades, os conselheiros repreenderam duramente os camaristas e, ao que tudo indica, os eventos passaram a ser objeto de maior atenção por parte das autoridades metropolitanas. Esse controle foi exercido pelos ouvidores, magistrados nomeados pelo rei, que tinham entre suas atribuições tomar as contas das câmaras, para evitar gastos excessivos. No episódio acima descrito, percebe-se um esforço em torno da construção de um repertório de atividades que gravitavam em torno da família real e da Igreja, que gradualmente se enraizaram nas Minas.

Em 1727, foi encaminhada nova solicitação ao rei para que este considerasse os gastos cometidos pela municipalidade, em decorrência do casamento dos príncipes portugueses, "os serenissmos Principes nossos S. ${ }^{\text {; }}$; e da sereníssima S. ${ }^{\text {ra }}$ infanta D. Maria, com o sereníssimo Principe das Asturias, e infanta de Castella a s. ${ }^{\text {ra }}$ D. Maria Anna Victoria" (AHU. Caixa 12, Documento 29). A celebração promovida em Vila Rica havia sido autorizada 
pelo monarca, o que se comprovava pela correspondência do rei ao governador da Capitania, às vésperas da ocorrência do evento, dando notícia do matrimônio, que deveria ser comemorado pelos vassalos. Segundo o monarca:

sendo estas notícias de tão grande contentamento para todos os meus vassalos, é justo que como tais se festejem com todas as demonstrações de alegria que fosem possíveis, vos ordeno que nesta capitania se façam salvas e luminárias e o mais que é costume em semelhantes ocasiões. (RAPM, 1979, p. 267)

Ao contrário da festividade do ano de 1726, objeto de críticas por conta das grandes somas despendidas, os camaristas afirmavam que esta tivera anuência do governador que havia autorizado a festa com todos os "estilos". Por tal motivo, solicitavam ao rei que tivesse atenção aos gastos vultosos que foram feitos com uma grande profusão de eventos. Segundos os camaristas:

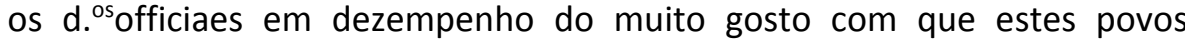
receberão esta noticia,querendo fazer mais plauzivel a sua celebridade se rezolverão a fazer, alem das festas ordinarias, as de touros, sortilhas, commedias, e serenatas com toda a grandeza conducente a hum tão heroico e digno motivo, no que fizerão hua larga despeza das rendas desta camara, prezumindo com justa razão, q V. Mag. ${ }^{\text {de }}$ em attenção do zello e affecto com que quizerão fazer mayor esta celebridade, madaria levar em conta a despeza que nella fizerão (AHU. Caixa 12, Documento 29).

Os gastos eram vultosos na mesma medida da grandiosidade da ocasião. Assim, as festividades eram do tamanho da importância da casa real, que deveria ser adequadamente celebrada entre os súditos. Pela profusão de gastos variados, solicitavam que o corregedor levasse em conta essas despesas, feita "em aplauzo de gosto de V. Magde, obsequio do Principe nosso S. ${ }^{r}$ e felecidade de seos vassalos" (AHU. Caixa 12, Documento 29). Na falta de uma resposta sobre sua demanda, os camaristas enviaram ao rei petição de igual teor no ano seguinte. E no ano de 1728, o rei determinou que, ao serem realizadas a correição dos gastos cometidos pelas Câmaras, fossem relevados aqueles referentes a algumas festividades. Segundo o texto:

Por provisão de $7 \mathrm{de} \mathrm{fev} .{ }^{\text {ro }}$ deste prez. ${ }^{\text {te }}$ anno ordena V. Mag. ${ }^{\text {de }} \mathrm{q}$ nas contas q tomar à camara desta va não leve em conta as despezas q se fizerão com as propinas e festas extraordinárias de feiras, cavalhadas e comedias pelos felizes desposarios dos sereníssimos principes; como tambem a despeza q se fez com hum [arco] q a mesma camara mandou fabricar na occazião da entrada q fez na d. . v. a o bispo; o q satisfiz, como consta da certidam junta sem attender aos repettidos requerim. ${ }^{\text {tos }} \mathrm{q}$ me fizerão os vereadores, propondo me; q as d. as $^{\text {as }}$ despezas com eff. ${ }^{\circ s}$ se fizerão poiz forão notorias as festas; e q tendo V. Mag. ${ }^{\text {de }}$ por sua real grandeza permitido se não fizesem 
das rendas da d. a camara os $d .{ }^{\text {as }}$ f. ${ }^{\text {as }}$ e sendo aquelles festejos movidos do aplauzo com q procuravam celebrizar tam singular occazião do $\mathrm{p}^{\text {ar }}$ agrado de V. Mag. ${ }^{\text {de }}$ e contentam ${ }^{\text {to }}$ geral de todos os vassalos esperavão q V. Mag. ${ }^{\text {de }}$ por sua real piedade os não obrigasse a pagarem aquillo de q se não utillizarão; poiz he as mesmas propinas haviao despendido, em luminarias e gallas de custo q fizerão; ao q tudo defferi recorressem a V. Mag. ${ }^{\text {de }}$ (AHU. Caixa 12, Documento 29).

Apesar da repreensão pelos gastos com as festividades por ocasião do nascimento do infante D. Alexandre, no ano de 1726, os gastos acabaram por ser autorizados. Afinal, as festividades deveriam ocorrer nas várias paragens dos domínios portugueses, de modo que seus súditos fossem festivamente informados sobre as efemérides da família real, consolidando o seu poder e presença entre os súditos.

Além dos casamentos, os nascimentos eram também parte importante da fixação da imagem da família real entre os súditos. Por ocasião do nascimento da infanta, o governador deu conta da ocorrência de festividades em Vila Rica e na Vila do Ribeirão do Carmo, no ano de 1737, informando que as demais também deveriam proceder às celebrações. Segundo o governador:

Meu S. ${ }^{\text {or }}$ nesta $V^{\text {a }}$ e na do Carmo se festejo o nascimento da Sr. ${ }^{a}$ infanta sem avizo q eu fizesse as camaras e so pela noticias q dei aos Ministros, quando me chegou; porque os Vereadores q estavasse servindo não quizeram deixar as propinas aos servidores: farei avizo circular as mais camaras na forma de que me ordena (Arquivo Nacional da Torre do Tombo, Manuscritos do Brasil. Livro 3, f.274).

Para que as festividades tivessem êxito, não eram medidos os gastos. Aqueles relacionados à família real consumiam parte considerável das receitas das câmaras. Em 1726, ano em que foram celebrados os casamentos dos filhos do rei D. João V, cerca de $42 \%$ da receita de Vila Rica referente a celebrações foi gasta no evento. Em 1735, essa câmara utilizou grandes somas com a celebração do nascimento da princesa da Beira (SANTIAGO, 2003, p. 49).

Além da celebração da vida dos membros da família real, a morte também ocupava espaço importante. Tal situação pode ser exemplificada com as exéquias, que eram cerimônias ou honras fúnebres que ocorriam em várias regiões do Império. Quando do falecimento de $D$. João $V$ no ano de 1750, várias paragens de Minas celebraram as exéquias com grande pompa e luxo. 
Ao tomar ciência do falecimento do Rei D. João V, a Câmara de Vila Rica, por meio de auto de vereação e 17 de dezembro de 1750, informou que fariam luto por seis meses, e todas as demonstrações públicas que eram de costume às "reais pessoas". Todos os moradores da Vila deveriam guardar luto e, caso não cumprissem esta determinação, teriam de cumprir 30 dias de cadeia, além de pagar quarenta oitavas de ouro (FUNERAIS de Dom João V, 1904, p. 361). Dias depois, os camaristas explicaram detalhadamente a programação que pretendiam cumprir. Feitos os avisos por todo o Termo da Vila, no dia 21 de dezembro os camaristas iriam quebrar os Escudos, ato em que um estandarte com as armas reais era partido ao meio, para representar a morte do Rei. Na ocasião, todos deveriam estar vestidos de "luto rigoroso" com capa comprida, portando uma vara preta. Seriam feitos três escudos, que seriam quebrados no Largo da Praça, no Largo da Igreja de Ouro Preto e no Largo da Igreja de Antônio Dias. O cortejo fúnebre que sairia do prédio da Câmara seria realizado da seguinte forma:

O Procurador do Sennado o Capitão José Correa Maya a cavalo com capa e casaca de baeta preta, levando ao hombro a dita bandeyra preta que arrastará no chão e hirá pegando nas farpas hum dos contínuos da Camera também vestindo de capa e volta, guiando o Cavallo pelas rédeas o Porteyro dos Auditorios em corpo vestido de luto regorozo, e assim montado será o primeyro que hirá marchando, e depois se seguirão oyto Meyrinhos, officiaes de justissa, ou os que houvessem promptos com capa e volta, e varas brancas (...) e em altas e intelligiveis vozes dirá estas palavras - choray Nobres - choray Povo - que he morto o vosso Rey (FUNERAIS de Dom João V, 1904, p.362).

Para que as exéquias fossem realizadas com esmero, os camaristas contrataram oficiais armadores e pintores para fazer ornamentos, e compraram veludos, galões e franjas. Mandaram entalhar uma essa com "perfeição e decência", feita por João de Souza Costa e Francisco Xavier de Brito. Contrataram também quatro coros de música, e um Sermão. Ações que foram acompanhadas pelas demais municipalidades de Minas Gerais.

Na Vila de São João Del Rei, as exéquias de D. João V foram celebradas pelos oficiais da Câmara. Segundo Affonso Ávila, "a cerimônia levada a efeito nas suas praças principais, durante a qual se quebraram os escudos do reino, ritual que se repetia tradicionalmente quando do falecimento dos soberanos portugueses". Naquela vila fora feito um obelisco funeral como uma homenagem póstuma ao soberano morto (ÁVILA, 1994, p. 172). Na 
Cidade de Mariana, as exéquias públicas foram igualmente pomposas. O inventário da câmara, datado de 1752, atesta a compra de quarenta e quatro côvados de veludo, destinadas ao "funeral do Senhor rei D. João V" para cobrir a essa, estrado elevado onde se deposita o caixão (Arquivo Histórico da Câmara Municipal de Mariana - AHMCMM, Códice 660, folha 15, 15v. e 16. apud Termo de Mariana,1998, p. 165). A partir dessas manifestações, a câmara participava a todos o falecimento do rei, confirmando na suntuosidade das celebrações sua importância. Mais uma vez, as Câmaras cumpriam a ação de consolidar a presença do rei pelas várias partes de seu império.

Por conta dos gastos promovidos pelas municipalidades, muitas vezes exorbitantes, o rei acabou por estabelecer em regimento as linhas gerais de ocorrência de celebrações nas vilas, a partir do regimento de 24 de maio de 1744. Para colocar um fim nos excessos, foram estabelecidos padrões de valores que deveriam ser recebidos pelas autoridades que participassem das festividades promovidas pelas Câmaras. Essa determinação estabeleceu as festas que as municipalidades mineiras deveriam promover obrigatoriamente, bem como as propinas que os camaristas deveriam receber para tomar parte nelas. Ali se estabeleceu o seguinte:

O juiz,vereadores, procurador e escrivão da câmara dessa vila cada um deles terá dez mil réis de propina em cada uma das quatro festas principais, que são corpo de Deus, Santa Izabel, o Anjo Custódio do Reino, e o dia do Santo Orado da Igreja Matriz dessa Vila: e havendo alguma ocasião de propina extraordinária aprovada por ordem minha, ou estilo obrservado em semelhante caso seja esta propina também de dez mil réis como as referidas: Nas mais festas em que por estilo dessa Vila tiverem propina dos rendimentos da câmara os oficiais dela terá cada um do sobreditos cinco mil réis somente (RAPM, 1896, v. 3, p. 501).

Com o regimento, a coroa esperava acabar com o problema dos gastos excessivos que eram cometidos pelos camaristas nas festividades. Muitos destes gastos foram apontados pelos ouvidores que, assumindo a função de corregedores, tomavam as contas dos oficiais das câmaras, desautorizando aquelas consideradas impróprias. Apesar dessa ordem, persistiram situações em que os camaristas exorbitaram o montante estabelecido pelo Regimento de 1744

Esta determinação foi um meio de frear as tensões relativas aos gastos promovidos pelas câmaras. Em muitos casos, estes continuaram a ultrapassar aquilo que era permitido pelo monarca, mesmo após 1744. Apesar dessas tensões financeiras eventuais, as 
festividades eram necessárias. Elas corporificavam a presença régia entre os povos, consolidando a presença desta junto aos vassalos. A composição simbólica de uma procissão, como a de Corpus Christi, elucida o aspecto simbólico do evento e denuncia seu tom hierarquizado. Os camaristas compunham o cortejo em honra do sacramento em lugar privilegiado, ladeando o pálio, carregando o estandarte do conselho, com as armas da coroa, e os juízes, devidamente paramentados, ostentavam suas varas. Estes atributos simbólicos, que anualmente eram "publicizados", criavam um espaço de "exaltação" do poder camarário, "favorecendo sua autoridade e a dignidade social de seus membros" (SANTIAGO, 2003, p. 93).

Há duas questões que chamam a atenção no tocante às festividades e às propinas que eram pagas aos oficiais das Câmaras. A primeira se referia ao fato de as festividades serem também um momento de afirmação do poder da própria Câmara, o que em muitos momentos era mais superlativado do que a festividade e seus objetivos - a celebração religiosa ou régia. Em uma sociedade hierarquizada, em que os aspectos simbólicos do poder eram cotidianamente necessários para traduzir os lugares e poderes dos povos e instituições, as festividades eram um meio útil de consolidar o poder das câmaras. Por meio do lugar que ocupavam nesses eventos, procuravam mostrar sua importância na administração, permitindo-os acumular um poder simbólico importante para serem respeitados pelos habitantes das vilas. Além das festividades, outras formas de afirmação do poder régio se fizeram presente nas Minas.

No inventário dos bens pertencentes à Câmara da Cidade de Mariana, datado de 1730, havia um retrato de D. João V, "de eterna memória", monarca português que se manteve no trono entre os anos de 1706 até 1750 . Além do retrato régio, o inventário de 1752 informa a posse de "um estandarte de damasco branco guarnecido com franja de ouro e armas reais". Em 1756, além dos bens descritos, consta o retrato de D. José, monarca que reinou entre os anos de 1750 e 1777. Em 1792, o inventário dava conta da existência de um retrato de D. Maria I, rainha de Portugal, entre os anos de 1777 e 1792 (AHCMM, Códice 660, folha 15, 15v. e 16 apud TERMO de Mariana, 1998. p. 163-165).

A produção e uso de imagens de governantes era difundido em várias regiões da Europa e tem seus primeiros registros ainda na antiguidade com as estátuas de governantes romanos. No período moderno, ganharam grande relevo, fazendo parte importante da 
fixação da imagem dos monarcas e seu poder. De tal maneira que os retratos de Luís XIV, expostos no palácio de Versalhes, deveriam receber constante atenção do espectador, não sendo permitido a este ficar de costas para as imagens. Segundo Burke, "que as pinturas e as estátuas tenham fornecido uma importante contribuição para a manutenção de determinados regimes ou não, acreditava-se largamente que elas assim o fizeram". Ao fazer tal apontamento, cita o cavalheiro Jaucourt, em escrita no ensaio "pintura" da Encyclopédie, para quem "em todas as épocas, aqueles que governaram sempre utilizaram pinturas e estátuas para melhor inspirar as pessoas com os sentimentos que lhes desejavam dar" (BURKE, 2004, p. 73-74).

Tendo em vista tal questão, a existência dos retratos citados nos inventários da Câmara de Mariana, instituição de grande importância no espaço urbano, bem como a existência de um estandarte com as armas reais portuguesas, pode ser visto como uma forma de "materialização" da presença de Portugal, que se corporifica na figura de seus soberanos, em Mariana, nas Minas, na América Portuguesa. Isso por ser possível localizar retratos de monarcas portugueses nas várias partes do Império, não sendo o caso da Câmara de Mariana uma singularidade. Teria sido assim um importante meio de dar "manutenção" à sua presença naquelas regiões. Por meio de seu retrato, os habitantes locais eram lembrados de sua existência e importância, a quem os ditos súditos deviam prestar sua fidelidade. Este "sentimento" era importante para a coesão e manutenção dos domínios além-mar.

A promoção de símbolos régios, por meio dos edifícios, das festividades e dos retratos, dá uma medida da preocupação existente por parte da Coroa em consolidar sua participação efetiva nas sociedades às quais estava relacionada. Esses feitos eram também um meio de consolidar a presença da autoridade e do poder nas Minas, recurso importante para o bom governo. É o que se depreende de uma correspondência emitida por Martinho de Mendonça Pina e Proença, governador da Capitania de Minas, entre 1736 e 1737:

Repetidas vezes tenho dito a V. Ex. a que Minas não é governo, em que se possa empregar um escudeiro de aldeia sem esplendor, ainda que com sangue ilustre, talento e fidelidade. As aparências exteriores da autoridade são o primeiro predicado, que se deve buscar para o governo das Minas, para que os povos lhe tenham respeito, os poderosos lhe obedeçam com menos repugnância e os ministros se persuadam, que $\mathrm{S}$. Majestade faz dele justa confiança. (CARTA de Martinho de Mendonça Pina e Proença ao secretário Antônio Guedes, 1896, p. 664-674) 
Por todo o exposto, notamos que construir e partilhar símbolos, ritos e formas de percepção do mundo foram meios úteis de consolidar o espaço de mando, bem como manter a sociedade coesa. Não bastava apenas a legislação e um aparato burocrático e militar, mas era necessária a sensação de que os habitantes de Minas Gerais faziam parte de um vasto Império, e eram vassalos da Coroa. Por todo o exposto, ao fundar câmaras na Capitania de Minas, entre os anos de 1711 e 1798, a Coroa Portuguesa não fez chegar apenas a administração aos povos, mas muito mais que isso. Permitindo que os camaristas promovessem a imagem do rei entre os súditos, fez com que sua presença pudesse ser sentida por seus vassalos.

\section{REFERÊNCIAS}

ANASTASIA, Carla Maria Junho. Vassalos rebeldes: violência coletiva nas Minas na primeira metade do século XVIII. Belo Horizonte: Editora C/Arte, 1998.

ÁVILA, Affonso. O lúdico e as projeções do mundo barroco II: área idade da áurea terra. São Paulo: Perspectiva, 1994.

BICALHO, Maria Fernanda. As câmaras ultramarinas e o governo do Império. In: FRAGOSO, João; BICALHO, Maria Fernanda; GOUVEIA, Maria de Fátima (Org.). In: O Antigo regime nos trópicos: a dinâmica colonial portuguesa (séculos XVI-XVIII). Rio e Janeiro: Civilização Brasileira, 2001, p.189-221.

BLUTEAU, Raphael. Vocabulario portuguez \& latino: aulico, anatomico, architectonico ...v. 8 Coimbra: Collegio das Artes da Companhia de Jesus 1712 - 1728.

BOXER, Charles R. O império colonial português (1415-1825). Lisboa: Edições 70, 2001.

BURKE, Peter. Testemunha Ocular: história e Imagem. Edusc, 2004.

CAMPOS, Maria Verônica. Governo de mineiros: "De como meter as minas numa moenda e beberIhes o caldo dourado" 1693-1737. 2002. Tese (doutorado em História) - Faculdade de Filosofia Letras e Ciências Humanas, Universidade de São Paulo, São Paulo, 2002.

CARTA de Martinho de Mendonça Pina e Proença ao secretário Antônio Guedes, 1896, p. 664-674.

CONSULTAS do Conselho Ultramarino, 1687-1710. Documentos Históricos. Rio de Janeiro: Biblioteca Nacional / Divisão de Obras Raras e Publicações, v. 93, p. 219-242, 1951.

FONSECA, Cláudia Damasceno. Arraiais e vilas d'el Rei: espaço e poder nas Minas setecentistas. Belo Horizonte: Editora UFMG, 2011.

FUNERAIS de Dom João V. Revista do Arquivo Público Mineiro, Belo Horizonte, v.9, n. 9, p.361-365, 1904.

SILVA, Antonio Moraes. Diccionario da lingua portugueza - recompilado dos vocabulários impressos até agora e, nessa segunda edição, novamente emendado e muito acrescentado, por Antonio de Moraes Silva. Lisboa: Typographia Lacerdina, 1789. 
OLIVEIRA, Pablo Menezes. Uma Capitania em transformação: a formação de vilas e a evolução sóciopolítica e econômica de Minas Gerais (1771-1791). 2005. 165f. Dissertação (Mestrado em História) Faculdade de Filosofia e Ciências Humanas, Universidade Federal de Minas Gerais, Belo Horizonte, 2005.

Ordenações Filipinas. v. 5. Rio de Janeiro: Tipografia do Instituto Filomático, 1870.

ROMEIRO, Adriana. Paulistas e emboabas no coração das Minas: idéias, e imaginário político no século XVIII. Belo Horizonte: Editora UFMG, 2008.

RUSSEL-WOOD, A.J.R. O governo local na América Portuguesa: um estudo da convergência cultural. Revista de História, São Paulo, v.55, p.25-81, 1977.

SANTIAGO, Camila Fernandes Guimarães. A Vila em ricas festas: celebrações promovidas pela câmara de Vila Rica (1711-1744). Belo Horizonte: C/Arte, FACE/FUMEC, 2003.

TERMO de Mariana: História e Documentação. Mariana: Editora UFOP, 1998. 